\title{
New Urbanization: The Driving Force of Building a Comprehensive Well-off Society*
}

\author{
Linxin Ye \\ School of management \\ China West Normal University \\ Nan Chong, China \\ E-mail: 15422800642qq.com
}

\begin{abstract}
This passage interprets the connotation of the new urbanization and the comprehensive construction of a well-off society, and analyses the relationship between them.Combining with the current status of the economic and soci al development of our country, we believe that the new urbanization will be an important force to promote the comprehensive construction of a well-off society in China. To further prove the important role of new urbanization in China's economic development, the article establishes the VAR patter and analyzes the data of urbanization and economic development since reform and opening up, the results shows: the urbanization increases one percentage point will drive economic development by 4.5 percentage points. It is proved that the new urbanization is an important way to promote the building of a well-off society in an all-round way.
\end{abstract}

Keywords—new urbanization; comprehensively build a well-off society; VAR patter

\section{INTRODUCTION}

" Eighth session of the Fifth Plenary Session" period is the decisive stage of building the well-off society in China. Building comparatively well-off society in the round by 2020 is the first goal of the "first two-hundred- -year goal" determined by the Communist Party of China. Whether or not to build a moderately prosperous society on schedule has a decisive role in the realization of the second century and the great rejuvenation of the Chinese nation. At present, the key and difficult points of building a well-off society in an allround way are the countryside and the farmers, and the core is the construction of new urbanization. Especially in the current background of China's economy entering into the new normal, China's economic society faces many contradictions, risks and challenges, and the new urbanization is considered as the new engine of economic and social development in China in the present and the future. Therefore, in the sprint stage of building a well-off society, we need to firmly grasp and use the new urbanization of this important development strategy and core role.

* Fund Project: National Education Ministry of education in 2015 (item number: 201510638018)

\section{NEW URBANIZATION AND THE CONNOTATION OF THE COMPREHENSIVE WELL-OFF SOCIETY}

\section{A. Connotation of New Urbanization}

Although there is no unified definition of urbanization at home and abroad, but it is generally can be summarized as social changes, economic structure change and space structural transfer three levels. The first is from the perspective of social changes, urbanization is the transformation of rural residents to urban residents, it reflects the increase in urban population, the expansion of urban built-up area and the formation of new urban lifestyle. The second is the transformation of economic structure, the urbanization is the process of gradually transforming the labor force from the first industry to the second, the three industrial transfer and industrial structure upgrade process. The third is the space structural transfer, the urbanization is a variety of production factors to the urban agglomeration and the re diffusion process. Different from the old urbanization, the new urbanization is mainly reflected in the promotion of this space, economy, and social structure changes in the process of development goals, development ideas, development model, development and innovation on the path of development. Mainly reflected in four as pects:

- Development goals: from speed to quality.

- Development concept: from "the oil urbanization "to "human urbanization".

- The development model: from "from top to bottom" to "bottom up".

- The development mode: fro m rough to intensive.

\section{B. Connotation of Comprehensive Well-Off Society}

The "well-off society" was put forward by Deng Xiaoping at the end of the 80's in the late 1970s when planning the blueprint of China's economic and social development. With the development of socialis $m$ with Chinese characteristics, the connotation and significance of the construction have been enriching and developing. At the end of the 20th century, the basic realization of the "well-off", the 18th meeting is put forward for the first time "to complete the goal of well-off society", and in the recently held the eighth session of the Fifth 
Plenary Session of the central to build a well-off society in an all-round way put forward new requirements, mainly reflected in the following points:

- The economy should maintain rapid growth, the GDP and per capita income of urban and rural residents in 2020 should be double of 2010 , the industry towards high-end level;

- The contribution of consumption to economic growth is significantly increased, the household population urbanization rate to accelerate.

- Agricultural modernization should make significant progress, people's living standards and quality should generally improve, the current standard of rural poverty population in rural areas should get rid of poverty;

- The national quality and the degree of social civilization should be improved;

- The ecological environment quality should be improved

- The system is more mature, and the national governance system and governance capacity modernization will make great progress.

\section{THE LOGICAL RELATIONSHIP BETWEEN NEW} URBANIZATION AND THE BUILDING OF A WELL-OFF SOCIETY IN AN ALL-ROUND WAY

As the two major process of China's modernization, new urbanization and building a well-off society in a comprehensive way will always run through the whole of China's modernization. Urbanization is a necessary process of modernization, it's also an important measure to measure the modernization, and a comprehensive well-off society is an important process to achieve modernization. From this logic, the new urbanization construction is an important process and the driving force to achieve a moderately prosperous society. Therefore, the new urbanization is an effective way to achieve a well-off society in an all-round way.

\section{A. New Urbanization is an Important Way to Solve the "Three Rural" Problems in China}

The difficulty and key point of building a well-off society is the countryside; the problem of "three agriculture" is an urgent problem to be solved in the development of economy and society in China. To rich farmers must reduce the farmers, to prosper the rural areas must advance urbanization. Reducing the number of farmers, increasing the amount of resources per capita in rural areas, increasing the per capita productivity, and thus enrich farmers, lead to a well-off society.

\section{B. New urbanization is an important means to achieve sustainable development}

New urbanization is that adhering to people-oriented, treating the new road to industrialization as a driving force, taking all factors into consideration principle, promoting urban modernization, urban cluster, urban ecology, rural urbanization, comprehensively enhance the quality and level of urbanization, the road of scientific development, intensive and highly efficient, function perfect, environment friendly, harmonious society, distinct personality, integration of urban and rural areas, large, medium and small cities and small towns coordinated development of urbanization construction road.

\section{New Urbanization Can Effectively Stimulate Domestic Demand, Driven By Economic Growth}

With the continuous improvement of the level of urbanization in China, the total population and consumption of urban population will be significantly improved, especially focusing on solving the "one hundred million three people", we will make the urban consumer groups continue to expand, the consumption structure continues to upgrade, the consumption potential of continuous release. New urbanization is an important starting point to promote industrial upgrading, it is also an important carrier to improve the quality and efficiency of economic development, it will bring huge investment needs of urban infrastructure and public service facilities and residential building. Especially the new "four modernizations", will open up new urbanization huge high quality investment growth space.

\section{EMPIRICAL ANALYSIS OF THE RELATIONSHIP BETWEEN NEW URBANIZATION AND ECONOMIC GROWTH}

\section{A. Index Selection and Data Sources}

According to the requirements of the econometric model and the object of this paper, we will select the following indicators: the new urbanization index-- the urbanization rate (URB), the economic development index--the per capita gross domestic product (GDP). Data are all from the calendar year, "China Statistical Yearbook".

\section{B. Building VAR Patter}

In order to eliminate price changes' effects to the results, this paper uses the price in 1978 as the base conversion into the actual value; at the same time, in order to eliminate the interference of heteroscedasticity's effects to the results. In this paper, I make the original data logarithm and get new sequences .I recorded them $\ln$ URB and $\ln$ GDP. I use the Eviews 6.0 software to deal the date.

\section{1) Stationary test}

In order to produce false regression, the ADF test method was used to test the stability of the VAR model, and the test results are shown in "Table I":

TABLE I. ADFTEST RESULTS

\begin{tabular}{|l|l|l|l|l|}
\hline & \multicolumn{4}{|c|}{ T-STATSTIC } \\
\cline { 2 - 5 } & \multicolumn{1}{|c|}{ NURB } & \multicolumn{1}{|c|}{ LNURBP } & \multicolumn{1}{|c|}{ LNGDP } \\
\hline $\begin{array}{l}\text { ADF TEST } \\
\text { STATISTIC critical }\end{array}$ & -2.08663 & -7.15649 & -1.43319 & -3.87706 \\
\hline $\begin{array}{l}\text { Test } \\
\text { values: 1\%level }\end{array}$ & & -4.25287 & -4.28458 & -4.28458 \\
\hline $\begin{array}{l}\text { Test critical } \\
\text { values: 5\%level }\end{array}$ & -3.54428 & -3.54849 & -3.56288 & -3.56288 \\
\hline $\begin{array}{l}\text { Test critical } \\
\text { values: 10\%level }\end{array}$ & -3.20469 & -3.20709 & -3.21526 & -3.21526 \\
\hline PROB.* & 0.5350 & 0.0000 & 0.8305 & 0.0254 \\
\hline Conclusion & $\begin{array}{l}\text { Non- } \\
\text { Stationary }\end{array}$ & Steady & $\begin{array}{l}\text { Non- } \\
\text { Stationary }\end{array}$ & Steady \\
\hline
\end{tabular}


According to the test results, the sequence of Lnurb and Lngdp is not stable, there is a unit root. After making a difference on the two sequences, the $\Delta$ Lnurb and $\Delta$ Lngdp are stationary, and there is no unit root. Therefore, the original sequence is a single integer time series.

\section{2) Co integration test}

According to the requirement of test results of unit root and integration test, the regression equation of the two variables is constructed as follows:

$$
\text { Lngdpi=4.5lnurbi-8.5+ui }
$$

$$
\begin{aligned}
(28.1) \quad(-15.5) & \\
R 2 & =0.96 \quad F=787.95
\end{aligned}
$$

From the results of $\mathrm{R} 2$ and $\mathrm{F}$, there is a high degree of correlation between the total and the variables of the regression equation. In order to further test whether the regression equation is false or not, it is necessary to carry out unit root test for the residual sequence of the regression result. If the residual sequence is stationary, it proves the regression equation is not false. ADF test results of the residual series are shown in "Table II":

TABLE II. RESIDUAL ETTEST RESUlts

\begin{tabular}{lccc}
\hline \hline & t-Statistic & Prob.* \\
\hline \hline Augmented Dickey-Fuller test statistic & -1.627612 & 0.0968 \\
\hline Test critical values: & 1\% level & -2.634731 & \\
& 5\% level & -1.951000 & \\
& $10 \%$ level & -1.610907 & \\
\hline \hline
\end{tabular}

According to table two test results show that the residual term is stable under $10 \%$ confidence level, there is no unit root, therefore, the regression equation is effective, and shows that there is a long-term stable equilibrium relationship between urbanization and economic development, that is, the rate of urbanization increased by $1 \%$ can lead to economic increase $4.5 \%$.

\section{3) Grainger causality test}

Grainger Granger causality test is an analytical method to analyze the relationship between economic variables. Through the above research, we can see that the urbanization rate and the per capita GDP two variables meet the conditions of the Grainger causality test. In order to further explore the bidirectional relationship between these two variables, this paper carries on the test of the Grainger causality test in this paper. By AIC test, it determined the maximum lag order of $\mathrm{P}=6$, the test results are shown in "Table III":

TABLE III. GRAinger CAUSALITY Test Results

\begin{tabular}{llrr}
\hline \hline \multicolumn{1}{c}{ Null Hypothesis: } & \multicolumn{2}{c}{ Obs F-Statistic Prob. } \\
\hline \hline LNURB does not Granger Cause LNGDP & 30 & 1.43589 & 0.2583 \\
LNGDP does not Granger Cause LNURB & & 2.88510 & 0.0398 \\
\hline \hline
\end{tabular}

According to table 3, the test results can be seen, in the lag order of 6, the urbanization is not the economic development of Grainger reasons, but the economic development is the Grainger reasons of urbanization. Therefore, from the view of statistics, the relationship between urbanization and economic development is not a two-way interaction, economic development can promote the development of urbanization, and simply rely on the improvement of urbanization rate cannot promote economic development. But in the long-term economic and social development process, the development of urbanization can effectively promote economic development.

\section{4) Impulse response function}

In order to reflect the impact effect between urbanization rate and economic growth, we can use impulse effect to analysis the lnGDP and lnurb of the urban population and the per capita GDP of the proportion of urban population. The selection of the asymptotic analysis method can get the results of "Fig. 1" by using Eviews6.0.

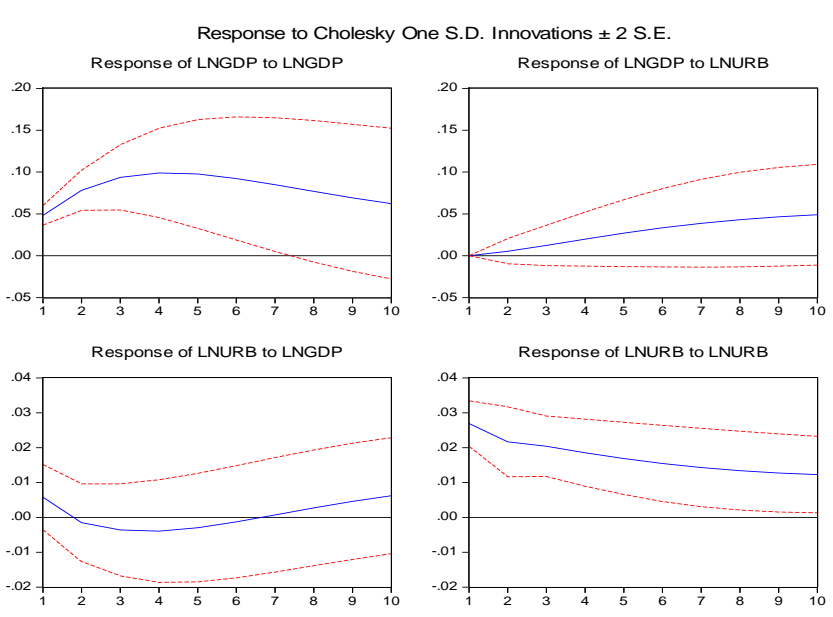

Fig. 1. Impulse response analysis

In "Fig. 1", the up-left image shows the impact of economic growth on its own image, it can be seen that the impact of GDP on its own in the first phase reached 0.5 of the response, and then has risen to fourth after the maximum value of 1 slow down, basically stable at more than 0.5 of the response level. The up-right image shows the impact of GDP on the rate of urbanization, fro $m$ the first phase of the zero response has been rising slowly, indicating that economic growth has a long-term positive response to urbanization. The down-left picture shows the response of the GDP to the analysis. In the first phase, In the first phase, the response to the economic growth is 0.5 , but in the second phase to the seventh is negative, and from the seventh period, urbanization has a positive effect on economic growth, which is consistent with the actual development of the law. The down-right chart shows the impact of urbanization on their own, in the first phase of the rate that is about 2.7 of the impact of the impact, and then the impact slows weakening.

Overall, the economic development and urbanization rate increase will have a positive impact on each other and continue for a long time, and the impact of economic growth on the proportion of urban population increase in a certain period of 
time will show up and eventually stabilize at a relatively stable level. The increase of urban population proportion impacts the economic growth in the short term that shows a significant impact, but the effect will decrease with the increase of the number of periods. It explains the mutual promotion between the economic growth and the proportion of urban population increase, the economic growth will slow down and continue to promote urban population, yet the increase in urban population has a great positive effect on short-term economic growth, but the stimulation effect will gradually reduce, after a long-term it will show a strong stimulating effect.

\section{CONCLUSIONS AND OUTLOOK}

Through the above analysis, the new urbanization has a significant impact and promotion on building well-off society .New urbanization is an effective way to build a moderately prosperous society in an all-round way, especially in the economic area, the rate of urbanization increased by 1 percentage point can drive economic growth by 4.5 percentage points. In the background of China's economy into the new normal, China's economic growth is slowing down, and the economy is weak, and it faces many contradictions. However, the vigorously promotion of new urbanization will open a huge investment, consumption and innovation space, it will be the important source to stimulate domestic demand and promote economic growth. Therefore, in the comprehensive construction of well-off society decisive stage, the party and the country must make full use of the new urbanization strategy, and vigorously implement the new strategy of urbanization, and play an important role in building a well-off society allround and achieving national modernization and the great rejuvenation of the Chinese nation.

\section{REFERENCE}

[1] Global network, China of the eighteenth session of the Fifth Plenary Session bulletin. http://finance.huanqiu.com/zcjd/201510/7870552.html.2015.10.29

[2] Berry B JL. City classification handbook: Method and Application [M].New York John Wiley \& Sons, 1970

[3] H. Chenery. Type of development (1950-1970) in the translation [M]. Beijing: Economic Science Press, 1988 (in Chinese)

[4] Dharmendra Dhakal, Pawel Mensz, Kamal P.Upadhyaya. Urbanization an Economic Growth in South Asia [J], SCMS Journal of Indian Management, 2010

[5] Paul. K. The Increasing Returns Revolution in Trade and Geography [J].American Economic Review,2009,99(3): 561-571

[6] United Nations. World Urbanization Prospects: The 2011 Revision. 2012.

[7] United Nations. WorldPopulation Prospects: The 2010 Revision. 2011.

[8] Binder MHCP.,2003,Estimation and Inference in Short Panel Vector Autoregressions with Unit Roots and Cointegration,Econometric Theory, Vol.21, PP795-837.

[9] Chen and Aimin, 2002, Urbanization and Disparities in China: Challenges ofGrowth and Development, China Economic Review, Vol. 13, PP407-411.

[10] Daniel Lederman and Claudio Bravo-Ortega, 2004,Is There an Urban Bias in Public Expenditures: A Welfare Approach,The World Bank Working Paper,Washingt on, DC. 